\title{
Modelling the water energy nexus: should variability in water supply impact on decision making for future energy supply options?
}

\author{
James D. S. Cullis ${ }^{1}$, Nicholas J. Walker ${ }^{1}$, Fadiel Ahjum ${ }^{2}$, and Diego Juan Rodriguez ${ }^{3}$ \\ ${ }^{1}$ Aurecon, Cape Town, 7441, South Africa \\ ${ }^{2}$ Energy Research Centre, University of Cape Town, Cape Town, 7701, South Africa \\ ${ }^{3}$ Water Global Practice, World Bank Group, Washington, DC 20433, USA
}

Correspondence: James D. S. Cullis (james.cullis@aurecongroup.com)

Received: 17 June 2017 - Accepted: 25 July 2017 - Published: 1 February 2018

\begin{abstract}
Many countries, like South Africa, Australia, India, China and the United States, are highly dependent on coal fired power stations for energy generation. These power stations require significant amounts of water, particularly when fitted with technology to reduce pollution and climate change impacts. As water resources come under stress it is important that spatial variability in water availability is taken into consideration for future energy planning particularly with regards to motivating for a switch from coal fired power stations to renewable technologies. This is particularly true in developing countries where there is a need for increased power production and associated increasing water demands for energy. Typically future energy supply options are modelled using a least cost optimization model such as TIMES that considers water supply as an input cost, but is generally constant for all technologies. Different energy technologies are located in different regions of the country with different levels of water availability and associated infrastructure development and supply costs. In this study we develop marginal cost curves for future water supply options in different regions of a country where different energy technologies are planned for development. These water supply cost curves are then used in an expanded version of the South Africa TIMES model called SATIM-W that explicitly models the water-energy nexus by taking into account the regional nature of water supply availability associated with different energy supply technologies. The results show a significant difference in the optimal future energy mix and in particular an increase in renewables and a demand for dry-cooling technologies that would not have been the case if the regional variability of water availability had not been taken into account. Choices in energy policy, such as the introduction of a carbon tax, will also significantly impact on future water resources, placing additional water demands in some regions and making water available for other users in other regions with a declining future energy demand. This study presents a methodology for modelling the water-energy nexus that could be used to inform the sustainable development planning process in the water and energy sectors for both developed and developing countries.
\end{abstract}

\section{Introduction}

International context and importance of the topic

Both energy and water are critical aspects of any economy, and yet despite their strong interdependence the two sectors are often managed independently (Hussey and Pittock, 2012). In resource use terms water is used to generate energy and energy is used to deliver, treat and supply water (Scott, 2011) (see Fig. 1) these links are referred as the water-energy nexus.

Developing an integrated approach to modelling the waterenergy nexus is critical to supporting the development of effective national policies and regulations to ensure continued economic development and growth in a sustainable way (Bazillian et al., 2011). 


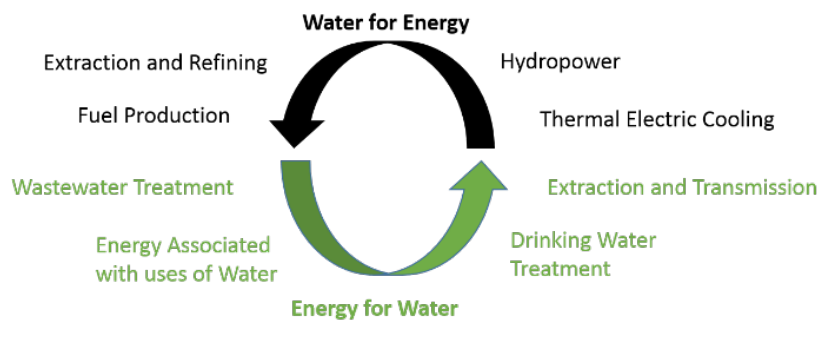

Figure 1. Defining the water energy nexus (after WEC, 2010).

Many countries, like South Africa, Australia, India, China and the United States, are highly dependent on coal fired power stations for energy generation. These power stations, however require significant amounts of water, particularly for cooling and when fitted with technologies to reduce pollution and climate change impacts.

Water availability is becoming more constrained in almost all countries through the combined effects of increasing demands, reducing water quality, and land use change. This presents a significant threat to future energy production (WEC, 2010). Similarly ever increasing water demands require consideration for more energy intensive technologies such as inter basin transfers (IBT), desalination and re-use of wastewater (Pittock, 2011).

As water resources come under ever increasing stress it is important that spatial variability in water availability is taken into consideration for future energy planning. Similarly, changes in energy policy are also likely to impact on water availability and also need to be taken into account for water resources planning and decision making.

This study seeks to make the link between energy and water resources policy and decision making through developing a linked water-energy nexus model. This study focuses on the water supply for energy generation part of the nexus. Specifically the objectives of this study are to incorporate regional variability in water availability and supply costs into an existing energy model so as to account for (1) a more representative cost of water supply to different technologies, (2) the spatial mismatch between water supply and the location of power plants, (3) the full cost of water supply to the energy sector including water supplied to mines, and (4) the opportunity costs of water use for energy production in a country with limited water resources and increasing demands.

South Africa was identified as a case study given its well documented water scarcity (DWAF, 2004), the importance of water for energy production, the extensive knowledge and strong analytical capacity for addressing the water-energy issue in the country, and the fact that the country is starting to plan water and energy in an integrated manner.

This South Africa case study is part of the World Bank's Thirsty Energy program and provides valuable knowledge and a framework for a water-energy nexus model that can be applied in other countries facing similar challenges relating to the water energy nexus (Rodríguez et al., 2013).

\section{Water energy nexus in South Africa}

\subsection{South Africa's energy mix}

Electricity supply in South Africa is dominated by a fleet of coal fired power stations operated by the state owned entity, Eskom. Eskom also functions as the system operator and owns and operates the transmission and distribution networks outside those owned and managed by the large metropoles. Eskom operates 22 power stations with a total nominal capacity of $41.9 \mathrm{GW}$, of which $85 \%$ of the capacity is coal-fired. The balance of capacity is provided by nuclear, open-cycle gas turbine, hydro and pumped-storage power plants (ESKOM, 2013). In an attempt to address energy diversification, environmental concerns, and economic growth aspirations, energy sources such as nuclear, gas and renewables are being examined as alternatives by the Department of Energy (DoE). Of particular concern is the large volumes of water used for cooling of existing coal fired power stations and the benefits that renewable and alternative energy supply options might also provide in terms of improved water use efficiency in addition to reduced carbon impacts.

\subsection{Water availability and supply}

South Africa is a water-scarce country (annual freshwater availability is less than $1700 \mathrm{~m}^{3}$ per capita), with limited average rainfall of about $450 \mathrm{~mm} \mathrm{yr}^{-1}$ and unevenly distributed water resources (DWAF, 2004). South Africa has an annual mean-runoff value of only $40 \mathrm{~mm}$ per capita, one seventh of the global average of $260 \mathrm{~mm}$, and rainfall and river flow are highly variable, erratic, and seasonal. Added to this is the fact that much of South Africa's key economic centres, including the urban and industrial centre of Gauteng, key mining areas and power stations, are located in areas of low water availability, far from major water sources where local demands exceed local supply. Out of necessity South Africa has had to develop a very proactive approach to water resources planning and supply which has resulted in a highly developed and integrated water supply system of large dams and many interbasin transfers to balance supply and demand. South Africa is the county with the 6th most number of large dams globally according to the International Commission of Large Dams (ICOLD), and with many kilometres of pipelines including large inter-basin transfer schemes (DWAF, 2004). Many of these have been developed primarily to provide water to coal fired power stations located in the Vaal, Mokolo, Olifants and Inkomati catchments. Nationally only about $2 \%$ of water is used for power production (DWA, 2013a), but in some catchments this can be as high as $40 \%$ and at a very high level of assurance. 
Table 1. Regional variability in potential power generation activities in each water supply region and associated WMAs.

\begin{tabular}{llll}
\hline WSR & WMA & Region & Activity \\
\hline A & Limpopo & Waterberg (Lephalale) & $\begin{array}{l}\text { Open-cast coal mining } \\
\text { Coal thermal power plants with FGD option } \\
\text { Coal-to-Liquids refineries }\end{array}$ \\
\hline B & Olifants & Mpumalanga, Witbank & $\begin{array}{l}\text { Open-cast and underground coal mining } \\
\text { Coal thermal power plants with FGD option } \\
\text { Coal-to-Liquids refineries }\end{array}$ \\
\hline C & Upper Vaal & Mpumalanga, Secunda & $\begin{array}{l}\text { Open-cast and underground coal mining } \\
\text { Coal thermal power plants with FGD option } \\
\text { Inland gas thermal power plants } \\
\text { Inland Gas-to-Liquids refineries }\end{array}$ \\
\hline D1 & Lower Orange & & $\begin{array}{l}\text { Concentrated Solar Thermal } \\
\text { Power Plants (CSP) }\end{array}$ \\
\hline \multirow{2}{*}{ D2 } & Lower and Upper Orange & Northern Cape, Karoo & $\begin{array}{l}\text { Shale gas mining } \\
\text { Gas thermal power plants } \\
\text { Inland gas-to-liquids refineries }\end{array}$ \\
\hline
\end{tabular}

\subsection{Water supply and energy planning}

The long-term infrastructure planning process for the supply of both energy and water is well established through government departments. The planning of both resources has taken into account cost and scarcity of the other to various degrees, but to date integrated modelling of the bulk supply infrastructure of both systems has not been undertaken. Investigating the significance of these linkages and how they affect future water and energy planning requires the integration of water constraints into energy models and energy constraints into water supply models.

\section{The water energy nexus model}

\subsection{SATIM-W: A Water Energy Nexus Model}

The South African TIMES model (SATIM), a public domain energy systems model developed by the University of Cape Town's Energy Research Centre (ERC), is a suitable base model for integrated water-energy planning ${ }^{1}$. SATIM is a national energy system model built using the TIMES model generator, which was developed under the auspices of the International Energy Agency's Energy Technology Systems Analysis Program (IEA-ETSAP).

Typically future energy supply options are modelled using an optimization model such as SATIM that considers water supply as an input costs, but is generally constant for all technologies. It is however important to note that different technologies are located in different regions of the country with varying levels of water availability and associated infrastruc-

\footnotetext{
${ }^{1}$ More detailed documentation of SATIM can be found at: http: //www.erc.uct.ac.za/Research/esystems-group-satim.htm
}

ture development and supply costs. In order to address this limitation regional variability was introduced in to SATIM$\mathrm{W}$ and individual water supply options, include major investments in dams and transfer projects and water supply energy needs, were incorporated into the SATIM-W model so as to capture the water-energy interplay. Incorporating a regional cost and quality for water allows the model to examine potential trade-offs within the supply sector e.g. fuel extraction and processing, treatment of water, cleaning and flue gas desulphurization. Regional variability in the non-energy water demands were also included in the model as this affects the relative opportunity cost for water supply to energy in each area. The updated model, SATIM-W, allows these activities to be represented so that the model is responsive to the regional cost and availability of water and energy supply, connected to a single national demand-side representation.

\subsection{Water and energy production regions}

South Africa is divided into 19 Water Management Areas (WMAs). The location of these WMAs, relative to the different energy producing regions of South Africa are shown in Fig. 2. These regions include: A: Waterberg (Lephalale); B: Mpumalanga, Witbank; C: Mpumalanga, Secunda; D1: Northern Cape, Upington; D2: Northern Cape, Karoo (Fig. 2). The nature of the specific energy activity in each of these regions is given in Table 1. In each region the Department of Water and Sanitation (DWS), formally known as the Department of Water Affairs (DWA) has assessed all future water supply options and determined the available yield, estimated capital and operational costs, and average energy requirements (e.g. for the pumping of water or desalination or water treatment) (DWA, 2010a). 


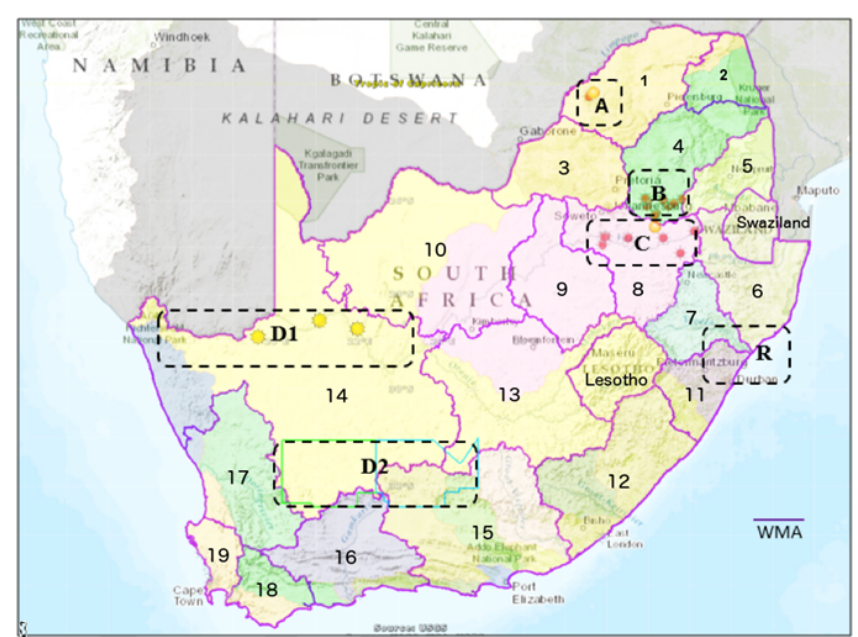

Figure 2. South African Water Management Areas and Energy Producing Regions (A: Waterberg (Lephalale); B: Mpumalanga, Witbank; C: Mpumalanga, Secunda; D1: Northern Cape, Upington; D2: Northern Cape, Karoo. The WMAs are numbers as per the original definition given in the National Water Resources Strategy (DWAF, 2004).

The regional distribution of water sources and consumers varies greatly in South Africa and as a result, the demand for water and supply is highly regionalized. For example, in the Waterberg district municipality (Lephalale) in Limpopo province, where the Waterberg coal deposits occur, the demand for water is dominated by water needs of the drycooled Matimba coal-fired power station for make-up water and other plant needs ( 4.3 million $\mathrm{m}^{3}$ p.a.), and the water requirements of its supplier, the Grootgeluk coal mine, which use water for coal washing $\left(9.9\right.$ million $\mathrm{m}^{3}$ p.a.). Together these two demands account for approximately $40 \%$ of the existing water withdrawals in the district. Energy sector withdrawals may grow to $75 \%$ by the year 2030 if further developments in coal-based energy supply are pursued (Aurecon, 2014; van Vuuren, 2006). Approximately $20 \%$ of current water withdrawals in the Waterberg region are directly attributed to electricity generation. This exceeds the availability of water in the local catchment area and has resulted in the construction of a major pipeline to transfer water in to the region from the neighbouring Vaal river system (Aurecon, 2011).

\subsection{Regional water supply cost curves}

A representative cost for water supply to the different energy producing regions was determined according to the $R e$ vised Water Pricing Strategy for Raw Water (DWA, 2012) and by using data provided in the analysis of the ultimate marginal cost of water supply to different regions in South Africa (DWA, 2010a). The unit cost of water supply for energy consists of the cost of the bulk infrastructure, delivery (transmission and distribution) and treatment requirements. The capital, fixed and variable operating and maintenance components are calculated separately in each water supply region for each water supply scheme (e.g., dam, inter-basin transfer) as part of determining the potential regional water supply cost. Where possible these costs have been updated with more recent cost estimates for specific schemes and regions (Aurecon, 2011; DWA, 2009, 2010b, 2013).

The marginal cost for water supply also increases with increasing demands and hence it was important to consider the impact of other non-energy water demands in each region and to develop a regional marginal cost curve for water supply as a function of the total demand in the region. This was also important in that the cost of water could also vary depending on when the proposed energy developments take place as future water supply options are generally more expensive than the current supply costs.

The resulting regional marginal cost curves for water supply are then included in the model associated with each region and SATIM-W then weights each water supply and delivery option (or scheme) and chooses the combination that delivers the needed water at least-cost, resulting in the determination of the total marginal water supply cost.

The costs for delivery of water to power plants is based upon estimates for deploying and managing major water supply and transfer schemes, but does not capture final details (and associated costs) that can only be determined when a specific site is identified. This is also true for hydraulic fracturing and Concentrated Solar Power where the exact locations and method of water delivery have not been determined. But in both cases these are rather small compared to the other costs characterizing each scheme.

\section{Model scenarios and results}

In order to assess the benefits of integrating the regional variability of water supply costs into future energy supply planning, two model scenarios were considered. The first scenario considered water supply as a uniform cost applied to all future energy supply options. The second scenario included the regional marginal costs of water supply as well as the other non-energy water demands relative to the locations in which the different future energy supply options where located. The results of these scenarios are given in Figs. 3 and 4 respectively. In order to model the potential impacts of climate change policy on future energy and water supply, a number of other scenarios were considered, including a limit on the total production of $\mathrm{CO}_{2}$, as well as a dryer future scenario due to climate change. The results are shown in Fig. 5.

\section{Discussion}

In the absence of taking into account the regional variability of water supply and associated infrastructure costs (the No 


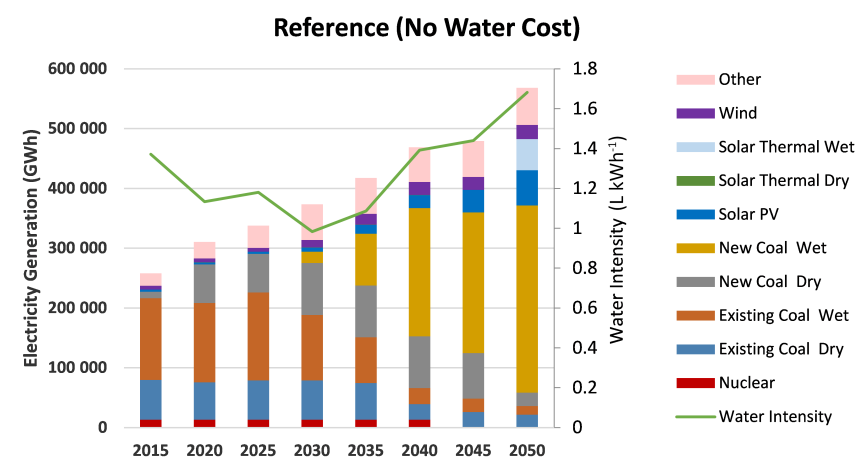

Figure 3. Optimal future energy mix under the reference scenario with no regional variability in water supply costs.

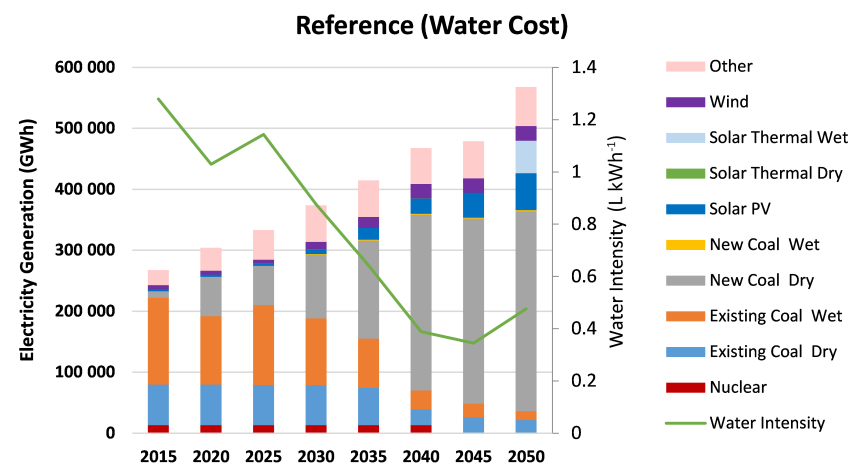

Figure 4. Optimal future energy mix under the reference scenario but with regional variability in water supply costs.

Water Cost scenario - Fig. 3), wet-cooled coal power plants are the preferred choice due to their lower investment costs and higher net generation efficiencies. However, when consideration is given to the regional variability in water supply (the Water Cost scenario in Fig. 4), dry-cooling is the preferred option for new coal power plants, particularly in the Waterberg region where the remaining economically viable coal reserves are located. New dry-cooled capacity of approximately $40 \mathrm{GW}$ is commissioned by 2050 and includes the replacement of the existing stock of $37 \mathrm{GW}$ which will mostly be retired by then. This SATIM-W result indicates that Eskom's dry cooling policy is really in the economic interests of the country, even though it increases the cost of electricity from coal power plants. This has a significant impact in terms of future water use efficiency in the power sector, which could either reach a peak of $1.65 \mathrm{~L} \mathrm{kWh}^{-1}$ by 2050 based on the No Water Cost scenario, or $0.5 \mathrm{~L} \mathrm{kWh}^{-1}$ based on the Water Cost scenario. In absolute terms, the inclusion of regional water supply cost cuts the cumulative (2010-2050) water consumption for the power sector by 9338 million $\mathrm{m}^{3}(77 \%)$ with just a modest increase $(0.84 \%)$ in the system cost.

Other than water consumed by power plants, the two scenarios have similar total system cost, energy supply expen-

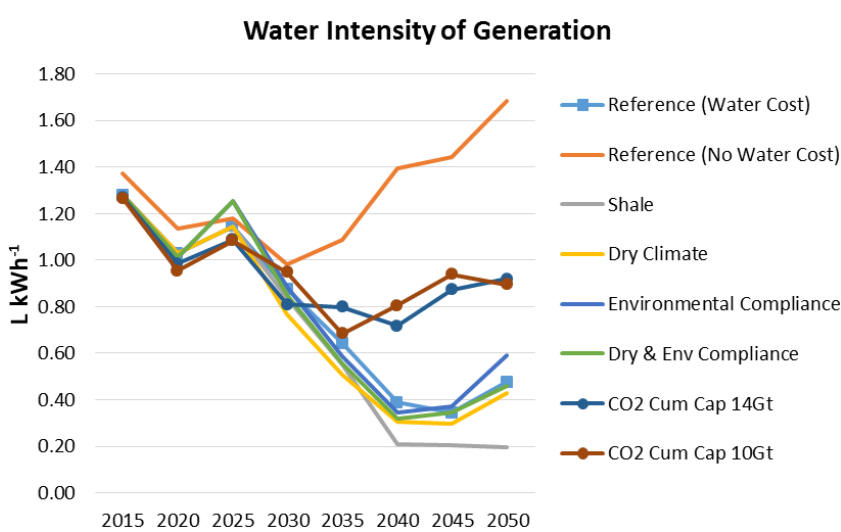

Figure 5. Resulting power sector water consumption and efficiency $\left(1 \mathrm{kWh}^{-1}\right)$ under different model scenarios

ditures, and primary and final energy consumption. Interestingly, the Water Cost scenario produces slightly more $\mathrm{CO}_{2}$ emissions in spite of generating $1.3 \%$ less electricity with coal and 2\% more with RE technologies (chiefly wind and solar PV, which require no water to generate electricity). This results from the reduced efficiency and higher unit emissions that are associated with the dry-cooled coal plants that are adopted when water costs are taken into account.

The impact of climate change policy, such as imposing a carbon limit on the energy sector, results in a significant shift in the optimal future energy mix. In particular this results in increase demand for renewables, but particularly concentrated solar power (CSP). The result of this is surprisingly an increase in the overall water use efficiency for energy production as shown in Fig. 5 as compared to the reference case Water Cost scenario which is dominated by dry-cooled coal fired power stations. The imposing of a carbon cap also has a significant impact on future water resources planning as it looks to develop more CSP plants, which are located in along the Orange River at the expensive of existing coal fired power stations in the Olifants and Upper Vaal catchments or new coal in the Lephalele area. This could result in a shift in water demand leading not only to stranded assets in terms of decommission power stations, but also the existing bulk water distribution systems that have been developed over the year to supply these power stations with water.

\section{Conclusions and recommendations}

These findings illustrate the insights gained from integrated and regionally disaggregated water-energy modelling and in particular the importance of taking in to consideration the regional variability in water supply costs and associated locations for different energy technologies. The main message from this study is that water and energy planning should be integrated. The analysis also shows the ability to identify major water infrastructure investments that could be- 
come stranded (or sub-optimal from an economic perspective) in light of possible future energy policy changes and can thereby help to formulate hedging strategies aimed at minimizing the likelihood of these stranded assets. Alternatively however, the opportunity to utilise these "stranded" water infrastructure investments could represent a significant economic opportunity as these could be repurposed to provide water needed to support other activities in the region at a relatively low costs. Hence it is important not only that water and energy policy be considered together in the context of the water-energy nexus, but that this should also be integrated with regional economic development and planning particularly in the context of future climate change and other uncertainties. This study also does not include additional externalities such as impacts on water quality or the total impact on $\mathrm{CO}_{2}$ emissions. These can however be incorporated into the further development of the model and future research.

Data availability. UCT, the custodians of the model and model results can be accessed: http://energydata.uct.ac.za/.

Competing interests. The authors declare that they have no conflict of interest.

Special issue statement. This article is part of the special issue "Water security and the food-water-energy nexus: drivers, responses and feedbacks at local to global scales". It is a result of the IAHS Scientific Assembly 2017, Port Elizabeth, South Africa, 10-14 July 2017.

Acknowledgements. This work was made possible by the financial contribution of the Water Partnership Program of the Water Global Practice, World Bank Group which supports the Thirsty Energy Initiative The authors would also like acknowledge the support of the members of the Thirsty Energy program steering committee as well as the anonymous reviewers for providing additional guidance.

Edited by: Barry Croke

Reviewed by: Fortune Faith Gomo and one anonymous referee

\section{References}

Aurecon: Development of a reconciliation strategy for the Olifants River Water Supply System: water requirements and water resources report, Report to Department of Water Affairs, Pretoria, RSA, report no.: P WMA 04/B50/00/8310/6, 2011.

Aurecon: Modelling the Water Energy Nexus in South Africa Task 1 Report: Development of Regional Marginal Water Supply Cost Curves, Document prepared by: James Cullis and Nicholas Walker, Aurecon South Africa (Pty) LTD, for the World Bank Thirsty Energy Program, 22 September 2014, 2014.

Bazilian, M., Rogner, H., Howells, M., Hermann, S., Arent, D., Gielen, D., Steduto, P., Mueller, A., Komor, P., Tol, R. S. J., and Yumkella, K. K.: Considering the energy, water and food nexus: Towards an integrated modelling approach, Energ. Policy, 39, 7896-7906, doi:10.1016/j.enpol.2011.09.039, 2011.

Department of Water Affairs (DWA): Development of an Integrated Water Quality Management Plan for the Vaal River System Task 5: Water Quality Economic Impact Modelling Final Report, Department of Water Affairs \& Forestry, Pretoria, South Africa, Report No. PRSA C000/00/2305/4, September 2009.

Department of Water Affairs (DWA): Assessment of the ultimate potential and future marginal cost of water resources in South Africa DWA Report No. P RSA 000/00/125610, Department of Water Affairs, Pretoria, South Africa, September 2010a.

Department of Water Affairs (DWA), Integrated Water Resource Planning for South Africa: A Situation Analysis, Report Number: P RSA 000/00/12910, Department of Water Affairs, Pretoria, South Africa, 2010b.

Department of Water Affairs (DWA), Revised Water Pricing Strategy for Raw Water III, Draft for comment, Department of Water Affairs, Pretoria, South Africa, available at: www.dwa.org.za, 2012.

Hussey, K. and Pittock, J.: The energy-water nexus: managing the links between energy and water for a sustainable future, Ecol. Soc., 17, 31, doi:10.5751/ES-04641-170131, 2012.

Pittock, J.: National climate change policies and sustainable water management: conflicts and synergies, Ecol. Soc., 16, 25, 2011.

Scott, C. A., Pierce, S. A., Pasqualetti, M. J., Jones, A. L. Montz, B. E., and Hoover, J. H.: Policy and institutional dimensions of the water-energy nexus, Energ, Policy, 39, 6622-6630, doi:10.1016/j.enpol.2011.08.013, 2011. 